\title{
PROTEST, REPRESSION, AND RACE: LEGAL VIOLENCE AND THE CHICANO MOVEMENT
}

\author{
IAN F. HANEY LÓPEZ ${ }^{\dagger}$
}

\section{INTRODUCTION}

Until the late 1960s, the Mexican community in the United States thought of itself as racially White. 'That is not how Anglos thought of Mexicans, of course. Largely beginning with the nineteenth-century period of intense Anglo-Mexican conflict in the Southwest, Anglo society perceived Mexicans as racially separate and inferior. ${ }^{2}$ By the 1920s, the Mexican community responded to this negative racialization by insisting that they were White. ${ }^{3}$ Leaders of the community

\footnotetext{
'Professor, Boalt Hall School of Law, U.C. Berkeley. This Article is part of a forthcoming book that uses the rise of the Chicano movement in East Los Angeles to examine the nature of racial knowledge. I have previously published part of this larger project. See Ian F. Haney López, Institutional Racism: Judicial Conduct and a New Theory of Racial Discrimination, 109 YALE L.J. 1717 (2000) (proposing a model of institutional racism that focuses on unintentional behavior and applying this model to judicial conduct in cases involving Chicano movement activists).

I discuss nomenclature in the text. Infra notes 12-15 and accompanying text. Note here that I draw on a social constructionist understanding of race. See Ian F. Haney López, The Social Construction of Race: Some Observations on Illusion, Fabrication, and Choice, 29 HARv. C.R.-C.L. L. Rev. 1, 6 (1994) (advancing a "theory of race as a social complex of meanings we continually replicate"); see also MICHAEL OMI \& HOWARD Winant, Racial Formation in THE UnIted States: From THE 1960s to THE 1980S (1st ed. 1986). I also capitalize all racial group names, "White" included. IAN HANEY LÓPEZ, WHITE BY LAW: THE LEgAL CONSTRUCTION OF RACE, at xiv (1996).

${ }^{2}$ See generally Reginald Horsman, RaCe AND MANIFEST DestinY: THE ORIGINS OF AMERICAN RACIAL ANGLO-SAXONISM (1981) (discussing developments in Anglo-Saxon racial identity and the racial construction of Mexicans during the American-Mexican War).

See Mario T. Garcia, Mexican Americans: Leadership, IDEOlogy, \& IDENTITY, 1930-1960, at 29-38, 42-53 (1989) (describing the "Americanization" efforts of Mexican Americans). To be sure, members of the Mexican elite had previously insisted on a White identity for themselves. See Tomás Almaguer, Racial. Fault Lines: THE HISTORICAL ORIGINS OF WHITE SUPREMACY IN CALIFORNIA 54-56 (1994) (discussing, for example, how at the California State Constitutional Convention of 1849 delegates such as prominent rancher Don Pablo de la Guerra argued that the term "white" should include Mexicans). See generally Robert F. HEIZER \& ALAN F. ALMQUisT, THE OTHER Californians: PRejudice and Discrimination under SPAIN, MEXICO, and THE UNITED STATES TO 1920 (1971) (outlining the history of racial discrimination against non-Anglo groups in California). Nevertheless, the late 1920s marked the moment
} 
claimed that Mexicans were Caucasian and thus White biologically, deserving the same social status and civic position as the White group. ${ }^{4}$ This belief in a White identity predominated among those who came to call themselves Mexican Americans. ${ }^{5}$ To some extent, members of this political generation successfully demanded from Anglo society recognition of their claims to a White identity. ${ }^{6}$ To take one example, although the U.S. Census Bureau enumerated a "Mexican race" in 1930, the Bureau bowed to political pressure from the Mexican community thereafter and in 1950 and 1960 counted that group as "White Persons of Spanish Surname." Despite these gains, in the late 1960s a large segment of the Mexican community reversed its racial selfconception, proclaiming a non-White identity. One of the hallmarks of the Chicano movement of that period was the assertion, still widely subscribed to today, that Mexicans form a separate race from Whites.

How did this transformation occur? Why did an emphasis on nonWhiteness arise in the late 1960s, when the community had fervently claimed a White identity during the relatively more racist 1940 s and $1950 \mathrm{~s}$, and had even made some progress in garnering official recognition of Mexican Whiteness? Was the claim of non-Whiteness a strategic choice, or did it reflect genuine conviction?

This Article explores these questions in the context of a particular

when leaders of the Mexican community began to argue that virtually all Mexicans residing in the United States were White.

${ }^{4}$ See Neil Foley, Becoming Hispanic: Mexican Americans and the Faustian Pact with Whiteness, in REFLEXIONEs 1997: New Directions in MEXICAN AMERICAN STUdies 53, 53 (Neil Foley ed., 1997) ("Mexican Americans began insisting on their status as Whites in order to overcome the worst features of Jim Crow segregation, restrictive housing covenants, employment discrimination, and the social stigma of being 'Mexican'....").

${ }^{5}$ I do not mean to suggest that every Mexican thought of herself or himself in exactly the same racial terms. Significant variation in self-understandings of racial identity existed and continues. It should be noted that racial self-conception among Mexicans, especially as it changes over time and as it varies by class and region, remains grossly understudied.

'See García, supra note 3, at 3 ("A political generation is distinct from a biological generation in that ... it is not age but politics that determines its character. A political generation consciously and politically reacts to its historical era." (footnote omitted)).

7 See, e.g., Bureau of THE Census, U.S. Dept. OF Commerce, U.S. Census of Population: 1960, Subject Reports, Persons of SPanish Surname, Social and ECONOMIC DATA FOR White PERSONS OF SPANISH SURNAME IN FIVE SOUTHWESTERN States, Final Report PC(2)-1B (1963). See generally Clara E. Rodríguez, Changing RACE: LATINOS, THE CENSUS, AND THE HISTORY OF ETHNICITY IN THE UNITED STATES (2000); Sharon M. Lee, Racial Classifications in the US Census: 1890-1990, 16 ETHNIC \& RACIAL STUD. 75, 78-79 (1993). 
criminal case that arose in East Los Angeles in 1968. In one week in late March 1968, over 10,000 students walked out of high schools serving the overwhelmingly Mexican East Los Angeles area. Some scholars mark this protest against terrible school conditions as the inception of the Chicano movement. ${ }^{8}$ The Los Angeles grand jury indicted thirteen activists on charges ranging from disturbing the peace to conspiracy for their roles in supporting the student protests. ${ }^{9}$ Many of the defendants were initially arrested and held without bail; they each faced possible sentences of forty-five years in jail. In what would be conducted as a political showpiece, the defense, led by a volatile attorney, Oscar Acosta, argued that the indictments were unconstitutional because the local judges had discriminated against Mexicans in selecting members of the indicting grand jury. ${ }^{10}$ The defendants in what came to be known as East LA Thirteen publicly denounced the trial as an exercise of judicial bigotry."

This case illustrates the shifting nature of Mexican racial identity during this period. It also highlights the role of law, and legal violence in particular, in the evolving racialization of Mexicans as nonWhite. I contend in this Article that legal violence, encompassing both judicial mistreatment and police brutality, substantially contributed to the emergence of a Chicano movement that stressed a nonWhite Mexican identity.

The discussion in Part II summarizes recent developments in the study of social movements. Part III considers the role of the AfricanAmerican struggle for equality in laying the groundwork for the Chicano movement. The largest section, Part IV, considers the particular contribution of legal violence to Chicano racial formation. Before turning to the principal text, though, a comment on nomenclature is

${ }^{8}$ Carlos Muñoz, JR., Youth, Identity, Power: The Chicano Movement, at xi (1989).

${ }^{9}$ People v. Castro, No. A-232902 (Cal. Super. Ct. 1968).

${ }^{10}$ Oscar Acosta memorialized his remarkable life and especially his years in East Los Angeles in OSCAR ZETA ACOSTA, THE AUTOBIOGRAPHY OF A BROWN BUFFALO (Vintage Books 1989) (1972); and OSCAR ZETA ACOSTA, THE REVOLT OF THE COCKROACH PEOPLE (Vintage Books 1989) (1973) [hereinafter ACOSTA, ReVOLT]. See also IlaN STAVANS, BANDido: OSCAR "ZeTA" ACOSTA AND THE CHICANO EXPERIENCE (1995) (chronicling Acosta's life until his disappearance in 1974).

${ }^{11}$ Although the defendants would lose their Fourteenth Amendment arguments, in 1970 they prevailed on free speech grounds. See Castro v. Superior Court, 88 Cal. Rptr. 500, 516 (Ct. App. 1970) (holding that the value of allowing the government to engage in a conspiracy prosecution based on circumstantial evidence was outweighed by the chilling effect on the "unfettered exercise of First Amendment rights"). 
required.

The term "Mexican" refers here generally to all permanent immigrants to the United States from Mexico and their descendants, as well as to persons descended from Mexican inhabitants of the southwestern region acquired in the mid-nineteenth century by the United States under the Treaty of Guadalupe Hidalgo. ${ }^{12}$ This term makes no distinction on the basis of citizenship. I employ this label in order to reserve for more particular usage the terms "Mexican American" and "Chicano." "Mexican American" became a popular designation among members of the Mexican community beginning in the late 1920s. Although to some extent it has lost any racial connotation, historically "Mexican American" arose as a term of self-description that carried with it an assimilationist ideology and an explicit claim to White racial identity. ${ }^{13}$ In this Article I use "Mexican American" when referring to members of the Mexican community whose social, political, and racial commitments include a subscription to the idea that Mexicans are White. "Chicano" became a common identification during the late 1960 s, especially among those who rejected the prior assimilationist orientation of the Mexican community. The term "Chicano" incorporated an assertion that Mexicans constituted a nonWhite race. ${ }^{14}$ As with "Mexican American," I use "Chicano" as a label for those who subscribe to specific racial claims, here non-Whiteness. Correspondingly, I seek to use "Mexican" in a manner that does not imply a specific conception of racial identity. "Mexican" serves as a default label bearing no specific racial connotations. ${ }^{15}$

My index of different terms to the various racial valences associ-

${ }^{12}$ A long-standing debate surrounds this term as well as others. See, e.g., RODOLFO ACUÑa, OCCUPIED AMERICA: A History OF CHICANOS, at x (3d ed. 1988) (discussing the racial politics involved in internal debates concerning group designation); MUÑOZ, supra note 8, at 7-12, 16 (same); see also Ian F. Haney López, Race, Ethnicity, Erasure: The Salience of Race to LatCrit Theory, 85 CAL. L. REV. 1143 (1998) (arguing that Mexican identity should be conceptualized in explicitly racial terms).

${ }^{13}$ See García, supra note 3 , at $42-53$ (describing the assimilationist ideology of LULAC, the League of United Latin American Citizens).

${ }^{14}$ On the Chicano movement, see generally IGNACiO M. García, Chicanismo: THE FORGING OF A MILITANT ETHOS AMONG MEXICAN AMERICANS (1997); and MuÑOZ, supra note 8.

${ }^{15}$ In this sense, my usage of "Mexican" does not share the same motivations as those animating its usage by Rudy Acuña. Acuña prefers Mexican to Mexican American because it accepts, reclaims, and valorizes an otherwise slighted identity, including the notion that Mexicans are non-White. RODOLFO F. ACUÑA, ANYTHING BUT MEXICAN: CHICANOS IN CONTEMPORARY LOS ANGELES 1, 8-9 (1996). 
ated with Mexican identity is uncommon. Few scholars make a similarly sharp distinction in usage, and among those who refer to themselves as Chicano or Mexican-American, significant variation exists regarding the nature of any implicit racial claims. Indeed, currently Chicano and Mexican-American often serve as synonyms. Nevertheless, using these labels in a manner that emphasizes their original racial connotations adds clarity to my overall discussion, and sharpens the argument that racial identity is a social, and sometimes legal, construction.

\section{SOCIAL MOVEMENT THEORY}

The development of a non-White identity within the Mexican community arose with the Chicano movement, an episode of broad political and cultural mobilization that can be partly explained by social movement theory. A quick overview of social movement theory in the United States is useful here. The classical scholarship of social insurgency stressed the importance of profound grievances. ${ }^{16}$ This model was criticized, first, because social movements often failed to occur even in the presence of significant social stress, and second, because the model relied on such extreme psychological responses as anomie, anxiety, and rage as the behavioral antecedents of social movements. $^{17}$ In response to these criticisms, students of social movements turned to accounts that emphasized resource mobilization, which stressed not simply the importance of external pressures, but also the necessity of local organizational resources. ${ }^{18}$ The resource mobilization model argued that external grievances were necessary, but not a sufficient cause in the absence of an ability to mount sustained challenges to the established social order." Under this model, technical skills, organizational density, capital, personal networks, and the political space in which to organize were all identified as important precursors to successful mobilization. The resource approach did not picture social insurgents as persons in the throes of heightened

${ }^{10}$ For good summaries of social movement theory as it has developed in the United States, see Doug MCAdAM, POlitical Process AND THE DEvelopment of BLACK INSURGENCY, 1930-1970, at 6-19 (2d ed. 1999); and Edward L. Rubin, Passing Through the Door: Social Movement Literature and Legal Scholarship, 150 U. PA. L. REV. 1 (2001).

17 MCADAM, supra note 16, at 12-16.

18 Id. at 20-35.

${ }^{19} \mathrm{Id}$. 
psychological states, but saw social movement activists as rational actors. $^{20}$

Current social movement theory continues to build on the resource mobilization model, but now posits that ideational resources may be as important as, or even more important than, organizational resources in explaining the rise of social movements. ${ }^{21}$ Reflecting the cognitive turn in the social sciences generally, the current generation of American social movement theorists emphasizes the importance of social cognition as an aspect of political insurgency. Sidney Tarrow stresses "cycles of protest" and "repertoires" in order to draw attention to the way in which social movements tend to follow patterns determined in part by learning curves among social actors. ${ }^{22}$ Doug McAdam uses the language of "initiator" and "spinoff" or "imitator" movements to indicate that later activists adopt the lessons taught by early insurgents. ".3 "[M] ost social movements," McAdam argues, "are caused by other social movements and the tactical, organizational, and ideological tools they afford later struggles."

Adopting a social constructionist approach, David Snow and Rob-

20 Id. at 20.

${ }^{21}$ But see Debra C. Minkoff, The Sequencing of Social Movements, 62 AM. Soc. REv. 779 (1997) (arguing that organizational density is the most important determinant of mobilization).

${ }^{22}$ Tarrow defines a "cycle of protest" as:

a phase of heightened conflict and contention across the social system that includes: a rapid diffusion of collective action from more mobilized to less mobilized sectors; a quickened pace of innovation in the forms of contention; new or transformed collective action frames... and sequences of intensified interaction between challengers and authorities ....

Sidney TARROW, POWER IN MOVEMENT: SOCIAL MOVEMENTS, Collective ACTION, AND POLITICS 153 (1994) [hereinafter TARROW, POWER IN MOVEMENT]; see also David A. Snow \& Robert D. Benford, Master Frames and Cycles of Protest, in FronTIERS IN SOCIAL MOVEMENT THEORY 133 (Aldon D. Morris \& Carol McClurg Mueller eds., 1992) [hereinafter FRONTIERS]. Tarrow argues that a "repertoire of contention" encompasses "not only what people do when they are engaged in conflict with others; it is what they know how to do and what others expect them to do." TARROW, POWER IN MOVEMENT, supra, at 31; see also CHARLES TILly, THE CONTENTIOUS FRENCH 4 (1986) (defining "repertoire of contention" as "the whole set of means [a particular group] has for making claims of different kinds on different individuals or groups"); Sidney Tarrow, Cycles of Collective Action: Between Moments of Madness and the Repertoire of Contention, in REPERTOIRES AND CYCLES OF COLlECTIVE ACTION 89, 91 (Mark Traugott ed., 1995) [hereinafter REPERTOIRES] (contending that historical moments of madness influence the slow evolution of the repertoire of contention).

${ }^{23}$ MCADAM, supra note 16, at vii-xxxvii.

${ }^{24}$ Doug McAdam, "Initiator" and "Spin-off" Movements: Diffusion Processes in Protest Cycles, in REPERTOIRES, supra note 22, at 217, 218. 
ert Benford draw heavily on the work of Erving Goffman to insist upon the importance of "framing." Snow and Benford, among many now, argue that the development of social movements depends to a considerable degree on innovations in the conceptualization of certain key problems, in particular regarding the nature of grievances, visions of potential futures, and, most importantly here, understandings of group identity. ${ }^{26}$ Current movement theorists posit that group

${ }^{25}$ According to Snow and Benford:

The term "frame" (and framework) is borrowed from [Erving] Goffman to denote "schemata of interpretation" that enable individuals "to locate, perceive, identify, and label" occurrences within their life space and [the] world at large. By rendering events or occurrences meaningful, frames function to organize experience and guide action, whether individual or collective.

David A. Snow et al., Frame Alignment Processes, Micromobilization, and Movement Participation, 51 AM. SOC. REV. 464, 464 (1986) (citation omitted). Notice that in suggesting the importance of frames, this approach significantly qualifies the image of social activists as rational actors. "It is a mistake to focus on collective action problems in terms of how people calculate likelihood of success. That calculation is in turn largely a function of frames within which they see a given problem." Id. at 470; see also William A. Gamson, The Social Psychology of Collective Action, in FrONTIERS, supra note 22, at 53 (discussing the use of social psychology to evaluate how an individual incorporates a collective action frame into her political consciousness); Scott A. Hunt et al., Identity Fields: Framing Processes and the Social Construction of Movement Identities, in NEW SOCIAL. MOVEMENTS: FROM IDEOLOGY TO IDENTITY 185 (Enrique Laraña et al. eds., 1994) [hereinafter NEW SOCIAL MOVEMENTS] (evaluating the interdependence between the framing process and the development of group identity and the resulting impact on collective action); David A. Snow \& Robert D. Benford, Ideology, Frame Resonance, and Participant Mobilization, 1 INT'L SOC. MOVEMENT RES. 197 (1988) (evaluating the conditions under which framing activities lead to mobilization); David A. Snow \& Robert D. Benford, Master Frames and Cycles of Protest, in FrONTIERS, supra note 22, at 133 (theorizing that the development of a master frame is a crucial factor in the development of mass mobilization); cf. Carol McClurg Mueller, Building Social Movement Theory, in FRONTIERS, supra note 22, at 3,4 (noting the social constructionist turn in social movement theory). See generally ERving GofFMan, Frame ANalysis: AN ESSAY ON THE ORGANIZATION OF EXPERIENCE (1974) (providing the initial sketch of frame analysis on which current notions have been built).

${ }^{26}$ The recent emphasis on identity in U.S. studies of social movements is indebted to the "new social movement" theory coming out of Europe. See, e.g., RON EyERMAN \& ANDREW JAMISON, SOCIAL MOVEMENTS: A COGNITIVE APPROACH (1991); AlberTo MeluCCI, NOMAdS Of THE PrESENT (John Keane \& Paul Mier eds., 1989); Alberto Melucci, A Strange Kind of Newness: What's "New" in New Social Movements? [hereinafter Melucci, Newness], in NEW SOCIAL MOVEMENTS, supra note 25, at 101 (evaluating the role and structure of social movements in highly complex information societies). However, note that the "new social movement" approach does not work from grievances and resources toward identity, but argues that a post-structural society marked by anomie leads citizens to construct identities around issues. See, e.g., Melucci, Neromess, supra, at 109-10 ("The production and reapportion of meaning seem to be at the core of contemporary conflicts ...."); see also id. at 117 ("The movement provided individuals and groups with a relatively stable point of reference from which to rebuild identities split 
identity exists in a dialectical relationship with social activism, with reconceptualizations of identity serving as spurs to insurgency, and in turn, with mobilization contributing to the development of new collective identities. ${ }^{27}$ The construction of collective identity is now understood to be a major antecedent to, as well as a significant accomplishment of, social movements. ${ }^{28}$

The recent emphases on initiator movements and identity framing are especially helpful in considering the Chicano movement. The remaking of Mexican group identity provided the basis for political mobilization in East Los Angeles. Yet, the Mexican community's turn to race as a basis of group identity cannot be understood except by reference to the African-American struggle for social and political equality as an initiator movement. Two particular aspects of the Black struggle greatly influenced the trajectory of the Chicano movement: the explicit articulation by Black Power proponents of a non-White identity as a basis for community solidarity and mobilization, and the conceptual link created by African-American protest between community demands for empowerment, racial identity, and legal repres-

among the various memberships, roles, and time scales of social experience."). Using the anti-nuclear, animal rights, and environmental movements as examples, this approach argues that issues or grievances may be less important than the identities that activism fosters. See generally NEW SOCIAL MOVEMENTS, supra note 25.

${ }^{27}$ Nancy Whittier emphasizes the importance of identity construction to social insurgency:

When individuals are immersed in a social movement, they internalize a new self-definition as part of a collectivity that interprets the world politically. Collective identity consists of three related processes: delineation of group boundaries, construction of an oppositional consciousness or interpretive frameworks for understanding the world in a political light, and politicization of everyday life. ... [C] ollective identity is an attempt to make sense of external events, experiences, and the movement context ....

Nancy Whittier, Political Generations, Micro-Cohorts, and the Transformation of Social Movements, 62 AM. SOC. REV. 760, 762 (1997) (citations omitted). Ron Eyerman and Andrew Jamison have also addressed this topic:

Social movements express shifts in the consciousness of actors as they are articulated in the interactions between activists and their opposition(s) in historically situated political and cultural contexts.... In other words, social movements are the result of an interactional process which centers around the articulation of a collective identity and which occurs within the boundaries of a particular society.

EYERMAN \& JAMISON, supra note 26 , at 4.

${ }^{28}$ As William Gamson remarks, "The creation of an ongoing collective identity that maintains the loyalty and commitment of participants is a cultural achievement in its own right, regardless of its contribution to the achievement of political and organizational goals." Gamson, supra note 25 , at 57. 
sion. I discuss these distinct forms of influence on the Chicano movement respectively in Parts III and IV.

However, as the discussion progresses, remember that social movements arise not simply out of the cognitive orientation of wouldbe activists, but also because of fundamental grievances, and then develop only where sufficient group resources exist. Profound social upheavals produce "moments of madness" when it seems possible to radically remake culture and society. ${ }^{29}$ The reality is almost always otherwise. The Chicano activists were not able to completely remake the basic terms of racial identity. Structural conditions lead to, but also limit, the success of insurgency, and social knowledge itself resists change, especially change in favor of disempowered social groups.

\section{THE AFRICAN-AMERICAN STRUGgLE FOR EQUALITY AS AN INITIATOR MOVEMENT}

Various social movement theorists have identified the influence of Black mobilization in the 1950s and 1960s on movements for women's liberation, gay and lesbian rights, and disability rights. ${ }^{30}$ In positing the African-American struggle as an initiator movement, and the other movements as imitators, social movement scholars frequently identify "rights" as the preeminent modality of Black protest." How-

297 See Aristide R. Zolberg, Moments of Madness, 2 POL. AND SOC'Y 183 (1972) (using examples from nineteenth- and twentieth-century France to evaluate periods of social upheaval in which "all is possible").

30) See, e.g., BARRY D. ADAM, THE Rise of a GAY AND LeSBIAN MOVEMENT 73-80 (rev. ed. 1995) (documenting the reorganization and increased militancy of the homophile movement to follow the example set by other social movements of the 1960s); DENNIS CHONG, Collective ACTION AND THE Civil Rights MOVEMENT 173-229 (1991) (modeling the unification and subsequent fracturing of various social movements in the 1960s); Sara Evans, Personal Politics: The Roots of Women's liberation in the CrVIL RIGHTS MOVEMENT AND THE NEW LEFT (1980) (tracing the role of women in the abolitionist and civil rights movements and the resulting impact on the women's rights movement).

${ }^{31}$ Doug McAdam exemplifies this tendency when he writes:

The ideological imprint of the civil rights movement is also clear in regard to the gay rights, American Indian, farm-workers, and other leftist movements of the period. All of these groups, drawing heavily upon the "civil rights master frame," came to define themselves as victims of discrimination and, as such, deserving of expanded rights and protection under the law.

Doug McAdam, Culture and Social Movements, in NEW SOCIAL MOVEMENTS, supra note 25, at 36, 42; see also TARROW, POWER IN MOVEMENT, supra note 22, at 129-30 (describing the core achievement of the civil rights movement as the combination of a "traditional rights frame" and "an innovative collective action repertoire"). 
ever, movement scholars rarely identify a turn to racial identity as a salient new development in popular protest. To some extent, the lack of attention to race by social movement theorists studying the influence of the African-American struggle reflects an emphasis on that part of the African-American struggle dominated by leaders such as Martin Luther King, Jr., and institutional actors such as the NAACP Legal Defense Fund and the Southern Christian Leadership Conference. ${ }^{32}$ This southern part of the Black movement stressed the rhetoric of rights over the language of race. The scholarly elevation of rights may also betray a bias in frame analysis toward the identification of a single "master" frame that in turn homogenizes movements in which multiple frames no doubt operate. ${ }^{33}$ Finally, the inattention to race may follow from efforts to study the influence of the Black movement on groups that did not organize themselves principally along racial lines. ${ }^{34}$ Nevertheless, greater attention should be given to race as a principal organizing element in many of the social movements of the 1960s. ${ }^{35}$ In the development of activism in the Mexican community, identity, and in particular racial identity, played a more important role than rights. For Chicanos, the most directly influential component of the African-American fight for social rights was not the southern organizing of the $1950 \mathrm{~s}$, but the Black Power movement of the mid- to late-1960s. Black Power exercised a direct influence on the Chicano movement because it established racial identity as the principal means of self-conception and group empowerment.

32 See, e.g., MCADAM, supra note 16, at 125-42 (discussing the "disproportionate role" played by Black churches, colleges, and the NAACP in the development of the civil rights movement).

33 See, e.g., McAdam, supra note 31, at 36, 42 ("One of the things that clearly linked the various struggles [of the 1960s] was the existence of a 'master protest frame' that was appropriated by each succeeding insurgent group. The source of this frame was the civil rights movement .....").

${ }^{34}$ Note, however, that even in the rare circumstance when other minority movements are mentioned, the focus remains overwhelmingly on rights. See, e.g., Snow \& Benford, supra note 22, at 149 ("[T] he flowering of movements such as those associated with women, Chicanos, American Indians, the aged, and the disabled ... was precipitated in part by the extension of the principle of equal rights and opportunities from the domain of black America to the situation of the other groups.").

${ }^{35}$ This is true even among those movements that did not conceptualize themselves in principally racial terms. Cf. McAdam, supra note 24, at 233 (noting the women's movement saying that "[w]omen are the niggers of the world"). 


\section{A. Black Power and the Chicano Movement}

Even before the first high school walkouts in East Los Angeles in 1968, local Mexican youth had met with Black Power activists. High school students in East Los Angeles formed a group called Young Citizens for Community Action (YCCA) in $1966{ }^{36}$ The next year, YCCA opened La Piranya, a coffee house and cultural center where activists introduced their causes to the community. ${ }^{37}$ Among the various speakers who met with the young activists of East Los Angeles were Black Power militants H. Rap Brown and Ron Karenga, as well as Stokely Carmichael, one of the architects of "Black Power" as a political rallying cry. ${ }^{38}$ In addition to meetings with Black Power advocates, a few Mexicans cut their political teeth in Black organizations. Elizabeth Sutherland Martínez, for instance, worked on civil rights in Alabama and in 1964 became the director of the Student Nonviolent Coordinating Committee office in New York. ${ }^{39}$ Indeed, East LA Thirteen lawyer Oscar Acosta also apprenticed in the Black struggle, spending four years working with the Black civil rights, movement while attending law school in San Francisco. ${ }^{40}$ These direct contacts between the Black Power movement and the leaders of the nascent Chicano struggle reflect the importance of personal networks-interpersonal relations within and between activist groups-in the rise of social movements.

${ }^{30}$ JUan Gómez-Quiñones, Mexican Students Por La Raza: The Chicano STUDENT MOVEMENT IN SOUTHERN CALIFORNIA, 1967-1977, at 17 (1998).

${ }^{37}$ RUBEN SALAZAR, Brown Berets Hail 'La Raza' and Scom the Establishment, in Border CoRresPondent: SElECTEd WrITINGS, 1955-1970, at 212, 216 (Mario T. García ed., 1995) [hereinafter BORDER CORRESPONDENT].

${ }^{38}$ Id. See generally STOKELy Carmichael \& Charles V. HAMILTON, Black Power: The Politics of Liberation In America (1967) (promoting the Black Power ideology as a political solution to society's racial problems).

99 MUÑZ, supra note 8, at 51; About the Editor to LETTERS FROM MISSISSIPPI (Elizabeth Sutherland ed., 1965).

40 OSCAR ACOSTA, Autobiographical Essay [hereinafter ACOSTA, Autobiographical Essay], in OSCAR "ZETA" ACOSTA: THE UNCOLLECTED WORKS 4, 7 (Ilan Stavans ed., 1996) [hereinafter UNCOLLECTED WORKS].

41 See generally Doug McAdam \& Ronnelle Paulsen, Specifying the Relationship Between Social Ties and Activism, in SOCIAL MOVEMENTS: READINGS ON THEIR EMERGENGE, Mobilization, AND DYNAMICS 145 (Doug McAdam \& David A. Snow eds., 1997) (arguing that personal ties to people involved in social movements encourages social activism). 


\section{B. Anti-Black Prejudice}

Yet, the experiences, lessons, and strategies of the Black Power movement did not speak exactly to the particularities of Mexican existence. Acosta remarked of his experience in the civil rights movement: “[I]t wasn't really me. I told people that it wasn't just black and white, that there were Chicanos, too...."42 The frustration Acosta expressed raises a larger point. Mexicans embraced the Black Power movement's model of identity mobilization, but they did so from the distinct social position they occupied in the Southwest. Like the other imitator movements that followed on the heels of, and adapted so much from, the Black fight for equality, the Chicano movement in East Los Angeles reflected many other influences as well. ${ }^{43}$

Perhaps most significantly, the lessons of the Black struggle were filtered through conceptions of Mexican identity already prevalent in that community. Recall that the Mexican-American generation saw themselves as a White group. This self-conception both drew upon and led to prejudice against African Americans, which in turn hindered direct relations between those two groups. ${ }^{44}$ In 1964, Mexicans overwhelmingly helped pass California Proposition 14, a voter initiative subsequently overturned on constitutional grounds, which barred local governments from prohibiting discrimination in the housing market. As a contemporary commentator remarked, "MexicanAmericans apparently failed to realize that the measure was directed against them as well as against the Negro." ${ }^{45}$ As late as 1965, main-

42 ACOSTA, Autobiographical Essay, supra note 40, at 7.

${ }^{43}$ Social movement scholars have been careful to emphasize that later movements adapt, rather than simply adopt, the lessons of earlier movements.

In arguing that initiator movements have a culturally catalytic effect on later struggles, I am not claiming that the latter are mere adopters of the ideas of the early risers. Instead I want to underscore the role of latecomers as creative adapters and interpreters of the cultural "lessons" of the early risers. ... [Often,] spin-off movements draw only the broadest inspiration from a given initiator movement, over time fashioning ideologies and specific cultural practices distinct from the movement(s) that set them in motion. Among the factors shaping variation in the cultural distinctiveness of latecomers is the extent to which the movement has access to a latent activist tradition or history of struggle that can serve as another "tool kit" into which the new generation of activists can dip for inspiration.

McAdam, supra note 24, at 229.

${ }^{44}$ See generally Foley, supra note 4.

45 Fernando Peñalosa, The Changing Mexican American in Southern California, in 
stream Mexican-American civil rights organizations positioned themselves in opposition to Black groups. For instance, shortly after the 1965 Watts riots in Los Angeles, the principal organizations of the Mexican-American generation, including the League of United Latin American Citizens and the GI Forum, sent President Lyndon Johnson a resolution that pointedly contrasted their assimilationist orientation with the militancy of the Black community. "The organizations argued that since Mexican-Americans did not believe in or engage in civil disobedience or violent confrontation, they were good citizens, loyal to the democratic system, and should be included in antipoverty programs." ${ }^{46}$

Thus, to make use of the Black experience, members of the Mexican community had to overcome both a strong assimilationist commitment and a strain of bias against African Americans. Their ability to do so came in part because the social turmoil of the late $1960 \mathrm{~s}$ highlighted the failure of the Mexican-American generation to achieve social and political equality, despite more than three decades of effort. This failure troubled even those formerly committed to assimilationist politics. For instance, Sal Castro, a high school teacher who actively supported the student protesters and who was indicted in East LA Thirteen, campaigned in the early 1960s for Democratic Party candidates for national and local offices. Castro was initially "a firm believer in the 'American Dream' [who] was on his way toward a successful political career." ${ }^{\text {"47 }}$ But by 1964 ,

Castro had come to the realization that the Democrats did not have the interests of Mexican Americans at heart.... A product of the barrio schools in East Los Angeles, Castro returned to the neighborhood as a teacher only to find that racism toward Mexican American youth remained virulent.... Castro came to the conclusion that his people needed their own civil rights movement and that the only alternative in the face of a racist educational system was nonviolent protest against the

Chicano: The Evolution of a PeOPle 255, 260 (Renato Rosaldo et al. eds., 1973).

${ }^{11 i}$ John R. Chávez, THE LOST LAND: THE CHICANo IMAge OF THE SOUTHWESt 133 (1984); see also RUBEN SALAZAR, Lain-Negro Unily Move Launched, in BORDER CORRESPONDENT, supra note 37, at 144, 146 ("Many Negroes say Mexican-Americans have been 'conspicuous by their absence' in the fight for civil rights. On the other hand, many Mexican-Americans say that they have had a long, painful and lonely battle for acceptance and that a coalition with Negroes now would set them back."); RUBEN SALAZAR, Negro Drive Worries Mexican-Americans, in BORDER CORRESPONDENT, supra note 37 , at 113, 113 ("[S] everal of the more conservative Mexican-American leaders strongly oppose any 'mixing' of Mexican-American and Negro grievances.").

${ }^{47}$ MuÑZ, supra note 8, at 65 . 
schools. ${ }^{48}$

Castro, like others who emerged as Chicano movement leaders, explicitly rejected the Mexican-American generation values he had earlier embraced.

For other members of the Mexican community, however, the Chicano movement served as their first introduction to political activity. Those Mexicans who cut their political teeth in the Chicano movement struggled against the general orientation of the community, but not against values they had previously relied on as the basis for political involvement. A literal generational shift in the Mexican community weakened the commitment to the values of the MexicanAmerican era. Far more so than their parents, the Mexican youngsters in Los Angeles and across the Southwest learned from and came to identify with the Black fight for equality. Los Angeles Times correspondent Rubén Salazar noted this aspect of intergenerational conflict:

Faced with an identity crisis, many young Mexican Americans-excited by black militancy-decided that they had been misled by their elders into apathetic confusion... . The ambivalence felt vaguely and in silence for so long seemed to crystallize in the light of the black revolution.

... There was talk now of brown power. ${ }^{49}$

Acosta also observed a generational element in regard to reactions to the walkouts and the defense allegations of judicial discrimination in East LA Thirteen:

The older, passive/fatalistic Mexican had become threatened by this sudden public attention now given to his race by the walkouts. His ancient fear of identification with the peon-translated "Black" in '68supported his need for anonymity.... And now this Grand Jury challenge accusing Superior Court judges of bigotry!

This fear of identification with Blacks played out through conflict between the youth and their parents. The older Mexican generation, more wedded to the ideals of White identity and assimilation, was

Id. at 65-66.

49 U.S. COMMISSION ON CivIL RIGHTS, STRANGER IN ONE'S LAND 2 (1970).

5o OSCAR ACOSTA, Racial Exclusion [hereinafter ACOSTA, Racial Exclusion], in UNCOLLECTED WORKS, supra note 40, at 280, 285. 
more likely to shun any association, actual or metaphorical, with Blacks. Members of the younger generation were more willing to take on a mantle of Blackness, and this generation became the vanguard of the Chicano movement. Whereas the Mexican-American generation eschewed contact with African Americans, the Chicano activists in 1968 and early 1969 largely embraced not only Blacks, but also Blackness. $^{51}$

\section{Mexican Activism Beyond, and Before, the East Los Angeles Movement}

The waning influence of Mexican-American assimilationist ideology both allowed and resulted from the increasing influence of Black activism in the Mexican community. However, other factors also pushed members of the Mexican community in Los Angeles toward an oppositional stance rooted in race. In particular, activism among Mexicans in other parts of the Southwest helped to catalyze the Los Angeles Chicano movement.

For instance, in the fall of 1965, César Chávez organized Mexican laborers in the first major strike against agribusiness in California's Central Valley. The farmworkers' struggle-union activity carried out on a nonracial and nonviolent basis-developed into the largest, and arguably the only nationally-prominent, mobilization of Mexicans in this period. Chávez's efforts inspired, both directly and indirectly, a

${ }^{51}$ I do not mean to suggest that members of the Chicano generation were all young or that youthfulness was the overriding determinant of movement participation. Nancy Whittier specifically warns against social movement theories that adopt "a developmental emphasis on adolescence as the sole formative period in individuals' lives." Nancy Whittier, Political Generations, Micro-Cohorts, and the Transformation of Social Movements, 62 AM. SOC. REV. 760, 762 (1997). Speaking directly about the Chicano movement, Ignacio García writes:

To argue that Chicano activists were predominantly youthful is to misunderstand cultural characteristics of the Mexican American community. The "youthful" activists were at an age when most of their peers were already working and taking care of families. This does not deny their youthful characteristics, but it should be pointed out that the successful organizations were those that tended to work with adults and that were not university based.... The reality of the Movement was not a large number of young people-or students-“raising Cain," but one of a community struggling to survive and control its destiny. Movement activities only became legitimate when older people and whole families supported them. Only when the elders of the community responded and created a generational link did the Movement have an impact.

GARCiA, supra note 14 , at 135 . 
wave of activism in Los Angeles and across the Southwest. ${ }^{52}$ Chávez traveled and spoke widely to garner support for the farmworkers and to encourage a more widespread political mobilization, appearing several times at rallies in Los Angeles. ${ }^{53}$ Two of Chávez's organizers moved to Los Angeles to work on La Raza, the leading movement newspaper there. ${ }^{54}$ Even Acosta felt Chávez's influence: a visit with Chávez during his fast in April 1968 helped Acosta decide to dedicate himself to the full-time defense of Chicano movement activists. ${ }^{5.5}$

Two other Mexican movements also contributed to Chicano militancy in Los Angeles. In contrast to the nonviolence exemplified by Chávez and the farmworkers, the land grant movement in New Mexico led by Reies López Tijerina provided a model of violent, armed protest. In rural New Mexico in the early 1960s, López Tijerina began to organize people around the issue of land titles, arguing that much of the land held by the federal government as national forest had been acquired by fraud from the region's Hispano inhabitants. ${ }^{56}$ Under the banner of La Alianza Federal de Mercedes (The Federal Alliance of Land Grants), López Tijerina's early strategies involved legal arguments over the meaning of the Treaty of Guadalupe Hidalgo, appeals to the Mexican government for assistance, and political pressure on elected and judicial officials. By 1966, however, these tactics segued into mass demonstrations, including the occupation of national forest

${ }^{52}$ According to Ignacio García:

The sight of poor Mexican American farmworkers in the picket lines, carrying a banner of the Virgen de Guadalupe, struck a nationalist nerve in many Mexican Americans. The fact that these semiliterate workers were organizing meetings, writing propaganda, and negotiating union contracts cast a new and more empowering light on Mexican Americans. These farmworkers had taken it upon themselves to change their condition, and they were doing it despite harassment from law enforcement agencies. This audacity to challenge agribusiness and its allies in state government galvanized a whole generation of Chicano youth to join the struggle for Mexican American civil rights.

GARCIA, supra note 14 , at $30-31$.

5.3 JOHN C. HAMmerback et al., A WAR OF WORdS: CHICANo Protest IN THE 1960S AND 1970s, at 33-36 (1985).

${ }^{54}$ Acosta quotes César Chávez as identifying "Risco and Ruth." ACOSTA, REvOLT, supra note 10, at 45. These are most likely Eliezer Risco and Ruth Robinson. LA RAZA, Sept. 16, 1967, at 2. Risco was among those indicted in East LA Thirteen.

5,5 ACOSTA, Revolt, supra note 10, at 45-47 (quoting Chávez as encouraging Acosta to continue "doing what has to be done").

${ }^{516 i}$ JuAn Gómez-QuiNones, Chicano Politics: REAlity \& Promise, 1940-1990, at 115 (1990). 
land. In one dramatic action in October 1966, López Tijerina and $L a$ Alianza occupied portions of the Kit Carson National Forest, took two law enforcement officers hostage, tried them for trespassing, and sentenced them to jail, before "mercifully" suspending the sentence and releasing them. ${ }^{57}$ Then, on June 5, 1967, while awaiting trial on the 1966 action, López Tijerina and armed members of La Alianza stormed the county courthouse in Tierra Amarilla, New Mexico, to make a citizen's arrest of a district attorney they considered abusive. A gun battle ensued, twenty hostages were held for about an hour, and a jailer and a state police officer were wounded. ${ }^{58}$ After almost one hundred years of quiescence, the actions of López Tijerina and $L a$ Alianza represented a resurgence of armed opposition to Anglo domination, and provided Mexicans across the Southwest with a model of authentically Mexican militancy. ${ }^{59}$

The Chicano movement in East Los Angeles was also inspired by a Denver, Colorado, organization called the Crusade for Justice led by Rodolfo "Corky" Gonzales. Like Sal Castro, Gonzales initially sought to improve the situation of Mexicans by following the route prescribed by the Mexican-American generation. ${ }^{\text {(i) }}$ However, by 1965, after stints as a precinct captain for the Democratic Party and as the director of Denver's War on Poverty, Gonzales came to favor increased activism. ${ }^{61}$ In 1966 he founded the Crusade for Justice, an organization that

57 ACUÑ supra note 12 , at 340 .

Id.; MuÑoz, supra note 8, at 57.

${ }^{59}$ On the early history of Mexican resistance to Anglo hegemony in the Southwest, see Robert J. Rosenbaum, MExicano Resistance in the SOUTHWEST 140-157 (S. Methodist Univ. Press 1998) (1981).

60 Se ERnesto B. Vigil, The Crusade for Justice: Chicano Militancy and the GOVERNMENT'S WAR ON DISSENT 8 (1999) ("In the 1950 s, Gonzales was a founding board member of the Latin American Educational Fund, the Colorado GI Forum, and the Latin American Research and Service Agency."). ficials:

il In resigning his positions, Gonzales wrote the following to Democratic Party of-

The individual who makes his way through the political muck of today's world, and more so the minority representatives, suffers from such an immense loss of soul and dignity that the end results are as rewarding as a heart attack, castration, or cancer! . . I can only visualize your goal as complete emasculation of manhood, sterilization of human dignity, and that you not only consciously but purposely are creating a world of lackeys, political boot-lickers and prostitutes.

Stan Steiner, La Raza: The Mexican AmeriCANS 383-84 (1969) (reprinting an excerpt of a letter from Gonzales to Dale R. Tooley, Democratic County Chairman in Denver, Colorado). 
spoke not to rural farmworkers or disenfranchised land holders, but to disenchanted Mexican urban youth. Gonzales more than any other brought the question of identity to the forefront of political mobilization. Whereas Chávez stressed labor, and López Tijerina focused on land, Gonzales placed Mexican identity at the center of his organizing.

Gonzales was the first prominent activist to attempt to rehabilitate the term "Chicano," theretofore often used pejoratively by Mexicans and Anglos alike. Gonzales' 1967 poem I Am Joaquin/Yo Soy Joaquín "became the epic story of the Chicano experience." ${ }^{62}$ In I Am Joaquin, Gonzales captured the cultural schisms that fractured Mexican identity, evoking not only those divisions rooted in the mixture of Spanish and Indian ancestry and culture, but also those engendered by the tensions between Mexican and American national identities. ${ }^{63}$ I Am Joaquin did not articulate the sort of racial conception of Chicano identity that soon developed in East Los Angeles. Instead, it depicted a racially and culturally fragmented self, as in the following passage:

I-am, Joaquin./I am lost in a world of confusion,/caught up in the whirl of an Anglo-/Society/..../The Victor/The Vanquished/I have killed/and have been Killed/..../Mejicano, Espanol, Latino, Hispano, Chicano/Or whatever I call myself,/I look the same/I feel the same/..../I am an Aztec Prince/and Christian Christ./I SHALL ENDURE! $!^{64}$

Nevertheless, in addressing the self-doubts and confusions at the heart of Mexican identity, Gonzales' poem dramatically put identity into question. I Am Joaquín, circulated on carbon copies and published in the first issue of La Raza in September 1967, and Corky Gonzales, and his Crusade for Justice more generally, spurred the rise of Chicanismo in Los Angeles.

${ }^{62}$ GARCiA, supra note 14, at 35. Acuña writes that Gonzales' "epic poem I Am Joaquin was probably the most inspiring piece of movement literature written in the 1960s. Its impact was immeasurable ...." ACUÑA, supra note 12, at 341 .

See MUNOZ, supra note 8 , at 61 ("I Am Joaquin... captured both the agony and the jubilation permeating the identity crisis faced by Mexican American youth in the process of assimilation.").

${ }^{64}$ Rodolfo Gonzales, I Am Joaquin, LA RAZA, Sept. 16, 1967, at 4-5. Carlos Muñoz comments, "Gonzáles did not advocate a specific identity for Mexican Americans in his poem: at the time he wrote I Am Joaquin he believed it possible to organize a movement regardless of the question of a specific identity ...." MUÑOZ, supra note 8, at 62 .

${ }^{65}$ Gonzales spoke often in Los Angeles, appearing at least three times from October 1967 to February 1968 alone. VIGIL, supra note 60, at 41, 50, 148. Oscar Acosta described Gonzales as "a poet, a street-fighter, a theorist and an organizer," adding "he 
The farmworkers, La Alianza, and the Crusade all contributed directly and dramatically to the development of Chicano activism in East Los Angeles. When students first marched in protest outside of Garfield High School in early March 1968, their chants included not just salutes to leaders of the Mexican revolution such as Pancho Villa and Emiliano Zapata, but also shouts of iQué Viva! to the names César Chávez, Reies López Tijerina, and Corky Gonzales. ${ }^{66}$

\section{Insurgency and Contingency}

Social movements reflect the social context in which they arise, including not only the lessons offered by other social movements but also the cultural and ideological resources of the mobilizing community. Identifying the Black fight for equality as an initiator movement that contributed to the development of Chicano insurgency in East Los Angeles does not lessen the importance of Mexican history in the Southwest. The innovations, imagination, and struggle of various Mexican leaders and groups directly influenced the rise of the Chicano movement. So too did other national and international influences, for instance the Cuban revolution and the global emergence of strong anticolonial movements. ${ }^{67}$ Anglo society's long-standing construction of Mexicans as a racial minority also formed a crucial part of the cultural context that facilitated the development of a Chicano identity. While the language of initiator and imitator movements may seem to imply a reductive, perhaps even mechanical process of direct transference or imitation, this is not the actuality. Instead, the Chicano movement's rise in Los Angeles reflected the confluence of various historical forces. The frustration of the Mexican community with the failure of its efforts to be recognized as White, the innovative actions of the farmworkers' movement, the New Mexico land grant struggles, and Colorado's Crusade for Justice all contributed directly to the Chicano movement.

is recognized by a lot of Chicanos as the boss, the leader." ACOSTA, Autobiographical Essay, supra note 40, at 10.

${ }^{\text {ifi }}$ ACOSTA, REVOLT, supra note 10 , at 40.

i7 See GómEZ-QuiÑonES, supra note 56, at 103 ("The aftermath of the Cuban Revolution, and later the African and Vietnamese liberation wars, galvanized Mexican consciousness about the conditions of Third World peoples within the United States. Changes in international relations contributed to the development of a nationalist perspective of the Mexican situation in the United States ...."); see also JOAN W. MOORE \& ALFREDO CUÉLLAR, MEXICAN AMERICANS 151 (1970) (citing the influence of the Cuban revolution on the Chicano movement). 
Nevertheless, Chávez, López Tijerina, and Gonzales all took lessons from the African-American movement. Chávez gave the nonviolence of Martin Luther King, Jr., a central role in the farmworkers' movement; and the 1965 Plan of Delano, which outlined Chávez's hopes for the farmworkers' movement, adopted King's steadfast optimism by embracing the African-American credo, "We shall overcome. ${ }^{\text {"i8 }}$ In contrast, López Tijerina and Gonzales drew the lesson of militancy from the African-American struggle: López Tijerina signed a "treaty" with leaders of the Black Panthers proclaiming, "[ $t]$ he two peoples agree, to take the same position as to the CRIMES and SINS of the Government of the United States of America," and, "Brown and Black should be together." "I learned from the Black movement. Look at Watts," Gonzales said. ${ }^{70}$ "The day after the riots the government was dumping millions of dollars to help the people.... I've been taught that five loose fingers by themselves are nothing. Bring them together and you have a fist." "11 The uniquely Mexican struggles for social equality led by Chávez, López Tijerina, and Gonzales fomented Chicano activism in East Los Angeles. Yet, we must also recognize the example that the Black movement set for each of these leaders and their respective movements.

A synergy existed between Mexican activism and the fight for Black equality. The Mexican leaders contrasted the initial successes of mobilized African Americans in their efforts to gain civil rights and improve government assistance with the failures of their assimilationist approach to achieving social, political, and material equality. In addition, the Black movement provided models of action for Chávez, López Tijerina, Gonzales, and their followers. Movements in the

\footnotetext{
${ }^{6}$ Luis Valdez, Plan of Delano, in AZTLÁN: AN ANTHOLOGY OF MEXICAN AMERICAN LITERATURE 197, 201 (Luis Valdez \& Stan Steiner eds., 1972).

${ }^{69}$ Brown $\mathcal{E}$ Black TOGETHER, LA RAZA, Oct. 29, 1967, at 5. Ignacio García argues that López Tijerina's influence among Mexican youth arose because his actions demonstrated the possibility of a militancy among Mexicans that rivaled that of Blacks:

To young Chicanos, awakened by the militancy of the Black Power Movement and antiwar protests, Tijerina seemed the epitome of the new Chicano leader.... Tijerina represented the macho, a real man who not only talked tough but had backed up his words by taking the law into his own hands. GARCía, supra note 14, at 33-34. As García's comments indicate, the Chicano movement developed in ways heavily influenced by gender ideology. I discuss this in my forthcoming book, mentioned supra note $\dagger$.

${ }^{77}$ VIGIL, supra note 60, at 10 (citing Frank Moya, Corky Gonzales Has Changed Little, ROCKY MTN. NEWS (Denver), Sept. 11, 1977).

${ }^{7}$ Id.
} 
Black and Mexican communities did not arise separately and simultaneously. Instead, activism among Mexicans began to accelerate almost a decade or more after African Americans started to mobilize for social justice. The Mexican youth in East Los Angeles drew on the innovative social protest of the Black movement, both directly and as filtered through the experiences and tactics of other Mexican groups. All of these influences, but perhaps most significantly the Black Power movement's emphasis on pride in non-White identity, contributed to the rise of a Chicano racial identity in East Los Angeles beginning in 1968. . $^{72}$

\section{Protest, LeGal RePRESSION, AND RACE}

The Black Power movement influenced activism in East Los Angeles by explicitly celebrating non-White identity. In addition, the African-American struggle of the previous decades had an even more pronounced, though indirect, effect on the rise of a conscious nonWhite Mexican identity. I contend that twenty years and more of Black activism revealed deep links between community protest, legal repression, and racial identity, and that those involved in the Chicano movement drew on these conceptual connections as the notion of a Chicano race evolved.

\section{A. Common Sense}

The connections among protest, legal repression, and race engendered by the Black movement were sometimes explicit. More importantly, and far more often, this triangular dynamic was "common sense." In referring to common sense, I make use of the social constructionism of such sociologists as Harold Garfinkel, Peter Berger, and Thomas Luckmann, who argue that social interaction occurs only to the extent that actors rely, often without conscious thought, on a

\footnotetext{
72 According to Edward J. Escobar:
}

The Black Power movement that evolved out of the urban rebellions of the mid-sixties ... used racial identity as a source of pride and a vehicle for political mobilization. Chicanos took this concept and reinterpreted it to create the concept of cultural nationalism, which became the ideological underpinning for the Chicano movement. Black nationalists also provided the militant rhetoric and confrontational tactics that practically all the other protest movements emulated.

Edward J. Escobar, The Dialectics of Repression: The Los Angeles Police Department and the Chicano Movement, 1968-1971, 79 J. AM. HIST. 1483, 1486 (1993). 
common intersubjective understanding of the context in which they find themselves. ${ }^{73}$ This common intersubjective understanding is what I mean by common sense. Current social movement theory, especially the new social movement literature, draws on similar ideas. ${ }^{74}$ To a considerable extent, African-American activism accentuated the common sense connection among protest, repression, and race. This link very often was seen but not noticed, relied upon but not considered-it became, in Garfinkel's language, part of "the world of daily life known in common with others and with others taken for granted."75

By 1968, the year of the first major protests in East Los Angeles, the African-American struggle had held the attention of the nation for years. Nightly television brought protest marches, sit-ins, freedom rides, swinging police clubs, snarling dogs, and spraying fire hoses into the homes of the Southwest. Place names like Selma, Montgomery, Birmingham, and Jackson evoked images of marches and police lines, demonstrations and mass arrests, protests and repression. Events in Detroit, Newark, and Watts also entered the public imagination, juxtaposing enraged faces, clamorous voices, milling mobs, and burning buildings with riot police, national guardsmen, sirens, and tear gas, all against a background of desperate urban poverty and extreme segregation. ${ }^{76}$ America seemed to be reduced to a place of rioting minorities, flame-engulfed cities, and massive police intervention.

${ }^{73}$ See Peter L. Berger \& Thomas luckmann, The Social Construction of REALITY 62 (1967); HAROLD GARFINKEL, STUDIES IN ETHNOMETHODOLOGY 275 (1967) (asserting that " $[t]$ he person in managing his daily affairs assumes a commonly entertained scheme of communication" that uses "a presupposed background of the "natural facts of life"). For a fuller discussion of the social constructionist argument I have in mind, see Haney López, supra note $\dagger$, at 1770-76.

${ }^{74}$ See, e.g., EYERMAN \& JAMISON, supra note 26, at 3 ("Action is neither predetermined nor completely self-willed; its meaning is derived from the context in which it is carried out and the understanding that actors bring to it and/or derive from it."); Enrique Laraña, Continuity and Unity in New Forms of Collective Action: A Comparative Analysis of Student Movements, in New SoCiAL MovemenTs, supra note 25, at 209, 217 ("A central assumption of the ethnomethodology approach is that a social movement is . . a temporal event, a process self-ordered on the basis of the members' knowledge and know-how, a collective and gradual production not only of the actors but also of receivers and observers."); Melucci, Newness, supra note 26, at 109 ("It is actors who, through their relations, produce and recognize the sense of what they are doing. But interaction is never an entirely overt process. It lies within the field of possibilities and constraints that actors observe and utilize.").

${ }^{75}$ GARFINKEL, supra note 73 , at 35.

${ }^{76}$ For an in-depth recounting of the social upheaval of the $1960 \mathrm{~s}$, see generally TODD Gitlin, The SiXTIES: YeARS OF HOPE, DAYS OF RAGE (rev. ed. 1993). 
Then, in April 1968, a month after the East Los Angeles walkouts, Martin Luther King, Jr., was assassinated in Memphis, Tennessee. And in June, days after the East Los Angeles indictments and arrests, Robert Kennedy, who had supported the walkouts and who had walked arm-in-arm with César Chávez, was shot to death in Los Angeles. As Chicanos in East Los Angeles mobilized around conditions in the schools and later around the arrests of community leaders in the spring of 1968, they did so in the midst of social upheaval and increasing violence.

The fight for Black equality made prominent seemingly natural connections among community protest, legal repression, and racial identity. The protesters were not the working poor, or a religious minority, or even people in general, but African Americans. The violence that met them was not wielded by society at large, but by White police forces and enraged White civilians, often backed by law enforcement personnel. Though it is obvious, the very fact that it is obvious both hides and reinforces the common sense significance of a core fact: The African-American struggle was at root a racial fight. In essence, the African-American movement involved a racial minority demanding social equality and political rights, only to suffer violent repression at the hands of a White majority and the police force it controlled. Black Power put racial identity into play explicitly, as a tool of community empowerment. But African-American activism as a whole put race into play implicitly. Minority racial identity emerged as a core concept for understanding legal repression as a response to community demands for empowerment. The ideas generated by Black insurgency-both conscious and common sense-facilitated mobilization by Chicano groups. ${ }^{77}$

${ }^{77}$ On this level, Black activism contributed to subsequent mobilization in the Mexican community more through the ideas it generated than through the strategic opportunities or political openings it created. Indeed:

Initiator movements may help to spawn later struggles, but the impetus for this process would appear to be cognitive or cultural rather than narrowly political.... [I]nitiator movements encourage the rise of latecomers not so much by granting other groups increased leverage with which to press their claims, but by setting in motion complex diffusion processes by which the ideational, tactical, and organizational "lessons" of the early risers are made available to subsequent challengers. ... . [T] he fundamental impulse to mobilization in the case of spin-off movements [is] essentially cognitive/cultural.

McAdam, supra note 24, at 226-27. 


\section{B. Race and Common Sense in East Los Angeles}

As Mexicans in East Los Angeles struggled to understand the prosecution of the East Los Angeles Thirteen and the legal violence affecting the community, many drew on the conceptual connections among community protest, legal repression, and racial identity to identify themselves as a racial minority. ${ }^{78}$ Evidence of the cognitive power of racial explanations emerges from the language and reasoning of the activists in the pages of $L a$ Raza, the leading activist newspaper in East Los Angeles. Published regularly between September 1967 and February 1970, the newspaper's editorial staff included two of the East Los Angeles Thirteen, and the paper's offices were raided by the police when making arrests in that case. ${ }^{79}$ Underground newspapers such as La Raza disseminated not only news but also new ways of thinking-the new frameworks supporting the rise of social activism. ${ }^{80}$

${ }^{78}$ It is no answer to the question of why Mexicans began to identify as a racial minority to note that, from an Anglo point of view, they were a racial minority. The Mexican community had long fought that designation. In addition, there were other lines along which they might have organized, including culture or national origin. As Bert Klandermans argues:

At the most general level, individuals can be classified in terms of structural categories such as class, gender, race, religion, ethnicity, nationality, and so on .... If we consider that individuals can be classified according to each of these categories and that there is no inherent reason an individual should identify with one rather than another, we will see that we need to find more specific factors to explain social identification.

Bert Klandermans, The Social Construction of Protest and Multiorganizational Fields, in FRONTIERS, supra note 22, at 77,94.

79) East LA Thirteen defendants Joe Razo and Eliezer Risco served on the editorial board of La Raza. LA RAZA, Mar. 31, 1968, at 11. Razo and Risco were handcuffed and arrested in the La Raza offices. Reddin Younger's Dog Pack Loose in East L.A., LA RAZA, June 7,1968 , at 5 .

80) Ignacio García offers the following observation:

[T] he Chicano press served as the catalyst for intellectual discussion. ...

These news sheets were in essence the wire service for Chicano activists throughout [the Southwest]. Articles that originated in the pages of these periodicals were reprinted in other newspapers, duplicated, and passed out during rallies or political discussions. This kept the flow of ideas going and bound all of the peripheries to the centers of Chicano activism. . . Much like radio and television for American society, the Chicano press developed a "mainstream" image of what a Chicano or Chicana in the Movement did or said.

García, supra note 14, at 58-59. To similar effect, Gerald Paul Rosen writes:

The underground papers have been extremely influential as a vehicle for articulating discontents and in creating a source of information for Chicanos interested in organizing and developing activities and organizations. There is 
Such papers thus constitute a unique record of the evolving common sense animating social rebellion, and La Raza is perhaps the best contemporary window through which to view the changing ideas underlying the Chicano movement in East Los Angeles. ${ }^{81}$

The articles published by $L a$ Raza repeatedly emphasized the connection between protest, law, and race. An article entitled Barrio and Ghetto Communities Protest Police Violence, published in La Raza in September 1968, provides an example of this analysis:

A potentially explosive situation has been created by the police department in East Los Angeles. The police have conceived a conspiracy against the Mexican people who are making just demands for social progress. In May, thirteen of our brothers were arrested and indicted, a newspaper was suppressed, and student leaders were jailed. Daily incidents involve the beating of teen-agers, constant citizen harassment on commercial streets, arrogant interfering with family social functions, and, of course, the daily insults meted out to Black and Brown people in their contacts with officers.

This paragraph tracks the connection between protest, legal repression, and race. First, it describes Mexicans as making "just demands for social progress." Second, it decries legal repression in the form of arrests, indictments, and jailing. Finally, it links these together with race, identifying Mexicans as "Brown people" and implicitly equating their identity with that of African Americans. In this last vein, consider a further excerpt:

also an important overlap in staff and writers between the papers and other movement organizations and it was not unusual to have reporters or photographers from the papers helping to lead or organize demonstrations. Founders of UMAS [United Mexican American Students], the Brown Berets, and high school student leaders have either worked for the papers or had close working relations with the papers.

Gerald Paul Rosen, Political Ideology and the Chicano Movement: A Study of the Political Ideology of Activists in the Chicano Movement 141-42 (1972) (unpublished Ph.D. dissertation, UCLA) (on file with author).

${ }^{81}$ Edward J. Escobar suggests the following:

Movement organizations communicated their message to the larger MexicanAmerican community through the Chicano media. In Los Angeles, newspapers such as Inside Eastside, the Chicano Student Movement, La Causa, and, most consistently, La Raza provided information and an analysis of it that Mexican Americans found nowhere else. By fostering the concept of chicanismo and by being openly and even stridently critical of American institutions, these newspapers created a Chicano counterideology.

Escobar, supra note 72, at 1492; see also Rosen, supra note 80, at 157 ("I think La Raza newspaper has done more than practically anything else as far as stimulating people.").

${ }_{82}$ Barrio $\mathcal{E}$ Ghetto Communities Protest Police Violence, LA RAZA, Sept. 3, 1968, at 5. 
We, Brown and Black, stand here together... hermanos unidos! We, Brown and Black, make this statement together, mano-a-mano, because we are one.

Although you have attempted to separate us by geography, a barrio here, ghetto there, we are in fact united by history.

Our oppressions are one.

Our dreams are one.

Our demands are one.

We suffer as one, we react as one, we struggle as one $!^{83}$

It is difficult to imagine a fuller equation of Mexican and Black identity. More importantly, however, note that the assertion of such commonality emerges in the context of community demands for social change and repressive police violence. This article exemplifies how the close interconnection among protest, police repression, and race accentuated by the African-American experience led some residents of East Los Angeles to see the exaggerated police and prosecutorial response to the walkouts as evidence that they were non-White. Some Mexican activists initially came to consider themselves functionally African American-they saw themselves suffering, reacting, struggling, and dreaming as if they were Black. ${ }^{84}$

\section{Framing an Understanding of East LA Thirteen}

The common sense of protest, repression, and race substantially influenced how the Mexican community in East Los Angeles framed the indictments and arrests in East LA Thirteen. Despite the participation of thousands of students in the March walkouts, and the involvement of some parents and community leaders in the subsequent negotiations with the school board, East Los Angeles in late May 1968

83 Id. (first ellipsis in original). The assertion of Black and Brown commonality was a common refrain. See Justice Under the Law?, LA RAZA, Sept. 3, 1968, at 4 (alleging a "triple standard of justice; one for the Brown and Black minorities, one for Anglos, and one for cops").

${ }^{84}$ "Especially during the early stages of a cycle," Doug McAdam argues, "the tactical choices made by challenging groups express their identification with the earliest of risers and signal a more inclusive and broader definition of the emerging struggle." McAdam, supra note 24, at 236. One sees here not just an adoption of tactics, but a robust identification with the protest initiators themselves, in this case African Americans. 
was relatively quiet. This quiescence came to a crashing end with the indictments and arrests that led to East LA Thirteen. The arrests galvanized the Mexican community. On the day after the arrests, 200 protesters gathered. On the day after that, Sunday, June 2, more than 2,000 people came together to protest the arrests-not in front of the Board of Education, the site of earlier, smaller demonstrations, but in front of the Los Angeles Central Police Station. ${ }^{85}$ At noon that Sunday, protesters formed picket lines around the station, defying the gathered police with chants of "Set Our Brothers Free-Now!" and "Chicano Power!" The school activists were there, of course. But now, so too were many folks who had not been involved in the March protests. Oscar Acosta observed that the arrests, much more so than the school walkouts themselves, mobilized the Mexican community in East Los Angeles:

While an anxiously precarious School Board negotiated publicly and in chambers with various committees and power structures, the Chicano militants agreed to call off their activist demonstrations and instead plunged into orthodox political activity behind a Mexican-American candidate to the state legislature. [However,] the seemingly cool prosecutorial officers of this bombastically flamboyant city of seven million transplants got uptight and nearly blew it.

... Immediately the traditional political activity ceased; the issues were no longer discriminatory education. Now it was abusive and excessive prosecutorial power by an unrepresentative government ....

The mobilizing effect of the indictments and arrests is historically important. Edward Escobar has examined at length the relation between police repression and political mobilization in East Los Angeles. ${ }^{88}$ Focusing on the late 1960s, Escobar persuasively argues "that

${ }^{85}$ Acosta notes that both the School Board and City Hall were considered and rejected in favor of protesting the police more directly. ACOSTA, REVOLT, supra note 10, at 55; see also Escobar, supra note 72, at 1497 (noting that the June 2 protest was the largest Mexican-American demonstration in Los Angeles' history).

${ }^{86}$ El Pueblo Responde al Grito, LA RAZA, June 7, 1968, at 8.

${ }^{87}$ ACOSTA, Racial Exclusion, supra note 50, at 282-83; see also Jay Lintner, Day of Collision, LA RAZA, July 10, 1968, at 6C.

${ }^{88}$ See, e.g., EdWARd J. Escobar, Race, Police, and THE Making of a POlitical IDENTITY: MEXICAN AMERICANS AND THE LOS ANGEles POLICE DEPARTMENT, 19001945 (1999) [hereinafter ESCOBAR, POLITICAL IDENTITY] (exploring how the deteriorating relationship between Mexicans and the Los Angeles police in the 1940s contributed to the formation of a Mexican-American identity); Escobar, supra note 72 (examining the relationship between police violence and political mobilization in East Los 
while police were using violence and intimidation against the movement, Chicanos were using the issues of political harassment and police brutality to increase participation in their movement. Police repression not only invigorated the Chicano movement but also helped to politicize and empower the Mexican-American community." Yet, of greater interest here is a point that Escobar notes, but does not develop or explain: "More dramatic and convincing than the rhetoric of any sixties activists, the LAPD's repressive tactics ... helped convince even conservative Mexican Americans that they, like African Americans, were an oppressed racial minority ...."90 Thus, more than simply mobilizing the Mexican community, legal violence contributed to the rise of a non-White Chicano identity.

At the outset, Acosta and the defendants struggled to understand the arrests and indictments in East LA Thirteen. For instance, the defendants initially charged that the prosecutions reflected local politics, noting that the arrests fell on the weekend preceding California primary elections." Defendant and La Raza editor Eliezer Risco hosted a news conference soon after the arrests to charge that District Attorney Evelle Younger, up for reelection, had targeted militants in the Mexican community in order to appear to be a "savior in a moment of danger." insofar as a police bond measure was on the early June ballot." In this

Angeles during the Chicano movement era).

${ }^{89}$ Escobar, supra note 72, at 1488. Escobar advances a similar thesis in his recent book, arguing that police repression encouraged the Mexican community to move toward an organized, rather than atomistic, politics. Escobar writes that no crisis "moved the Mexican American community to large-scale activism like the twin issues of the zoot-suit hysteria and the police misconduct of the 1940s. While other issues may have forced people to think of themselves as Mexican Americans, no other issue made people act politically as Mexican Americans." EsCOBAR, POLITICAL IDENTITY, supra note 88 , at 17 .

(1) Escobar, supra note 72, at 1514. Escobar also suggests that "the hostile police response to movement activity heightened Los Angeles Mexican Americans' sense that they were an oppressed and exploited people, especially in their relations with the police. This increased sense of exploitation, in turn, led to a greater feeling of ethnic solidarity within the Mexican-American community ...." Id. at 1508.

9ave Larsen, Editorial, Timing of Arrests in School Walkouts Called Political, L.A. Times, June 5, 1968, at pt.2, 1.

Id.

93 Id.; see also ACOSTA, REvOLT, supra note 10, at 54-55 (characterizing the arrests as "a political set-up" aimed at influencing the California primary elections). Younger called Risco's allegation "absurd," while Police Chief Tom Reddin responded that comments regarding the indictments and arrests should come from the District Attorney's office. Larsen, supra note 91. 
respect, La Raza made much of the fact that thousands of leaflets opposing the police bond measure disappeared from their offices during the raids that occurred simultaneously with the arrests. ${ }^{94}$

The charge that local politics explained the defendants' arrests did not detract, however, from what almost immediately emerged as the principal explanation of the police sweeps, multiple counts, and high bail: The defendants perceived their mistreatment to be a response to their demand for community empowerment. In their effort to understand the prosecutions, social marginalization and legal mistreatment ceased to be seen merely as misfortunes, and instead came to be understood as injustices spawned by racial hostility. ${ }^{95}$ Upon their arrest, five of the East LA Thirteen began a hunger strike. Consider the explanation for this action, offered in a letter from Joe Razo, one of the strikers, written while still in prison:

The [sic] have separated us and put the five of us: Risco, Razo, Cruz Olmeda, Moctezuma Eeparza [sic], and David Sanchez into one cell. We are entering our 3rd day on the HUNGER STRIKE. Make no doubt about it, WE ARE POLITICAL PRISONERS and we are paying for our political viewpoints. We are prepared to spend the rest of our days in jail to further the Chicano cause.

According to Razo, his arrest and prosecution and that of his compatriots resulted from their political viewpoints-that is, their demands for improved schools in East Los Angeles and social equality for the Mexican community. This claim identifies two of the three elements linked together by the African-American struggle, protest and legal repression. Notice that the third element, racial identity, also surfaces within Razo's claim: At root, it was as "Chicanos," and not simply as "persons" or even as "Mexican Americans," that the state targeted the defendants. The picket signs carried by protesters outside the courthouse on June 2 spoke with brevity and clarity to this third element, proclaiming, "Let My People Go" and "Withdraw Racist Cops."

94 See Armando Morales, ANdo Sangrando (I Am BleEding): A Study of MEXICAN AMERICAN-POLICE CONFLICT 78 (1972) (indicating that police, without search warrants, also took newspaper copy, mail, and photographs in addition to the several hundred thousand leaflets).

${ }^{95}$ See Snow et al., supra note 25 , at 466 (" $[\mathrm{T}]$ he emergence of a significant social movement requires a revision in the manner in which people look at some problematic condition or feature of their life, seeing it no longer as misfortune, but as an injustice.").

96itical Prisoners Speak, LA RAZA, June 7, 1968, at 7.

${ }^{97}$ See LA RAZA, June 7, 1968, at 8 (featuring photographs of the Chicano protesters 
The first issue of La Raza to report on the police sweeps and indictments was published a week after the arrests. Again, terms of the racial struggle model linking protest, law, and race stand out. The front page of La Raza, under the title "Noticia a la Jefe Placa" ("Notice to the Chief Cop"), proclaimed in bold letters:

Sunday, June 2, 1968, la Raza Nueva served notice on RED RED REDDIN, la Jefe Placa, that La Raza can no longer be intimidated... WE WILL BE HEARD FROM THE PRISON OF OUR BARRIOS AND OUR CELLS. Protest is poverty inspired, is frustration inspired... There is no hope in your "laws" in your "courts." Our only hope is in OUR OWN PEOPLE!! QUE VIVA LA RAZA NUEVA! $!^{98}$

An us-them rhetoric dominates this excerpt, placing "la raza nueva," "our own people," "our barrios," and "la raza" in opposition to "your 'laws," "your 'courts,'" and "la Jefe Placa." To some extent, this rhetoric reflects the extent to which events in early June shifted community attention from education to police-community relations. This shift effectively redirected attention from a matter largely internal to the community (the quality of schools in East Los Angeles) to a matter with a decidedly external component (relations with the police and the courts). ${ }^{99}$ By directing concern to forces outside of East Los Angeles, the arrests accentuated an us-them dynamic that doubtless contributed to the developing sense that something fundamental divided "us" from "them." Yet, this excerpt also highlights the terms of that divide, casting Mexicans as a people, a "new race" ("raza nueva"), standing against the police, an unjust force. ${ }^{100}$ Notice, too, that the fulcrum in this opposition is community protest. The racial struggle engendered by the African-American fight clearly provided the terms

and their picket signs).

${ }_{18}$ Noticia a la Jefe Placa, LA RAZA, June 7, 1968, at 1.

The activists, of course, had already adopted something of an external perspective, insofar as they sought to blame the school conditions on the indifference of the Los Angeles School Board, and by implication, the rest of society. Even so, the abrupt transition from a focus on school conditions to policing must have accentuated any insider-outsider dynamic already in play.

100 "La raza nueva," like "la raza" generally, does not necessarily invoke the concept of "race" as used in the United States. Instead, the use of "la raza" seems, at least initially, to have been intended to invoke the sense of "peoplehood" with which LatinAmerican usage imbued the term. Nevertheless, Mexicans using that phrase in East Los Angeles could not have ignored its resonance when translated into English as "race." It seems likely that this American sense of the word also informed its usage by the activist community, especially as Mexicans transitioned toward a non-White conception of themselves. 
by which the Mexican community immediately understood the arrests and indictments in East LA Thirteen.

Oscar Acosta also relied on the common sense connection between racial protest and repression in understanding East LA Thirteen. The following appeared in La Raza in July 1968 as part of an appeal for contributions to help defray legal expenses:

The Chicano Legal Defense Committee is a committee that was formed as a result of the police malpractices that occur daily in our barrios. Since we are poor financially, but not in spirit, we have seen the necessity of hiring a group of lawyers to defend our people who are actively attempting to change a racist system that has kept us down educationally, economically, politically and socially.

In the past two years Mexican-Americans have intensified their efforts to achieve dignity, equality and justice. This struggle, in disfavor by those in authority, has recently claimed 13 Chicanos in East Los Angeles. ... The least that you and I can do is contribute our personal and financial support. In doing so we will not only be helping to decide the fate of the 13 Chicanos but also our own. ${ }^{101}$

Again, the interconnection between protest ("efforts to achieve dignity, equality, and justice"), repression ("the police malpractices that occur daily in our barrios"), and identity ("Chicanos," "our people," "[our] fate") pervades Acosta's appeal. To be sure, Acosta does not explicitly proclaim the racial nature of Chicano identity. Nevertheless, he clearly implies this distinct identity by referring to "Chicanos" and by decrying "a racist system." The basic contours of the tripartite linkage established by the Black struggle for equality clearly set the terms by which Acosta framed his analysis of East LA Thirteen.

\section{Legal Repression}

The common sense connection between race, protest, and repression did more than accentuate the importance of race. As this background understanding of the social situation developed, each of its various aspects gained increased salience. In particular, Chicanos began to see legal repression not only as an explanation, but as a prediction. They began to expect that, as minorities engaged in protest, they would be subject to legal violence. Recall Joe Razo's jailhouse let-

${ }^{101}$ Chicano Legal Defense Fund, LA RAZA, July 10, 1968, at 6D. It is likely, though not certain, that as chief counsel for the Defense Fund and as a regular contributor to $L a$ Raza, Acosta drafted the appeal for funds. 
ter insisting that the militants were willing to spend their lives in jail to further the Chicano cause. ${ }^{102}$ Razo's words convey not just bravado but also pessimism about the defendants' futures. The pessimism in particular is striking, coming so early in the East Los Angeles activists' brush with law enforcement. This sense of foreboding also gripped Acosta. In September 1968, Acosta cautioned La Raza readers that they should not expect the defendants to prevail at the trial court level. in East LA Thirteen. "Since this is a political case from beginning to end, we can't necessarily expect [the judge] to rule favorably on the matter. After all," Acosta warned, "she too is a part of the system."103 From the outset, then, the defendants and defense counsel expressed pessimism about the way in which they would be treated under law. In part, this followed from memories of past encounters between the police, the courts, and the East Los Angeles community, with episodes such as the 1943 Sleepy Lagoon case still vivid in community folklore. ${ }^{104}$ However, such pessimism most likely also arose from the implicit interconnection between race and protest, and the expectancy this created regarding legal mistreatment. Understanding their prosecution as a reaction to demands for community empowerment, and as a reflection of their identity as racial minorities, the Chicano defendants did not expect justice or fairness from the courts. Rather, they expected repression.

For the Chicano militants, confirmation of this expectation came relatively quickly. In October 1968, Francisco Martínez was convicted on charges arising out of the walkouts. Not one of the Thirteen, Martínez was tried and convicted in municipal court on a misdemeanor count of disturbing the peace. According to the Mexican prosecutor, Ricardo Torres, "Martinez was taken into custody when he refused to stop leading a small group of students in loud chants after school had begun for the day." 105 Acosta argued on behalf of Martínez

${ }^{102}$ Supra note 96 and accompanying text.

10.3 La Raza Nueva 13, LA RAZA, Sept. 3, 1968, at 11.

${ }^{104}$ In 1943, East Los Angeles was roiled by the tainted trial and conviction, eventually overturned, of seventeen youths for murder. See ESCOBAR, POLITICAL IDENTITY, supra note 88 , at 207-32 (relating the basic facts of the Sleepy Lagoon trial and the subsequent response by liberals, Mexican Americans, and police officials). The trial occurred in the midst of growing hysteria regarding Mexican criminality. See id. at 229-32 (describing the escalating hysteria fed by rumor and provocative news stories); see also MAuricio MAZón, THE ZOOT-SUIT Riots: THE PSYChology OF SYMbOlic ANNIHILATION (1984) (arguing that the "Zoot-Suit riots" hold an elevated position of symbolic importance in the group memory of East Los Angeles' Mexican community).

${ }^{105}$ Ron Einstoss, Mexican-American Majority Opposes Boycott-Younger, L.A. TIMES, 
before Judge John Arguelles, one of the few Mexican judges, and a jury of eight Mexicans and four Anglos heard the case..$^{106}$ Acosta contended that the First Amendment insulated Martinez from conviction for the "crime" of carrying a picket sign and walking the sidewalk while shouting "Viva la Raza." In addition, Acosta also put Chicano activists on the stand to explain their philosophy and to read movement poetry. ${ }^{108}$ The prosecutor described the poetry as "poison," and Judge Arguelles ruled against the relevance of the First Amendment, stating that the "many 'Negro sit-in' cases" no longer accurately reflected the mood of the country. ${ }^{109}$ The jury deliberated less than two hours before convicting Martínez. ${ }^{10}$

After the conviction, Acosta published an article in La Raza explaining the significance of the Martinez case, and expressing deep skepticism about the possibility of Chicanos securing justice in the courts. "' Acosta wrote:

If both [sic] juries, prosecutors and judges, all Mexican-Americans, will no longer allow citizens to engage in nonviolent protest as the constitution and the Supreme Court have said they could, should these men jeopardize themselves any longer?

Should the time and money and frustrations be spent on such orthodox protests any longer? Especially if they are no longer effective?

Is it not time to go underground? Is it not time to put aside our poetry, our music and our romance until after the revolution? ${ }^{112}$

Acosta suggested that because legitimate protest led only to arrest and conviction, public demonstrations perhaps should be forsaken in favor of revolution. ${ }^{113}$ This conclusion seems extreme in the wake of a

Oct. 9, 1968, at pt. 2, 2.

106) Francisco Martinez Found Guilty, LA RAZA, Oct. 15, 1968, at 12.

${ }^{107} I d$.

$108 \mathrm{Id}$.

109 Id.

110 Id. In mid-1969 Acosta successfully appealed Martínez's conviction on free speech grounds. People v. Martinez, No. A-8347 (Cal. Super. Ct. 1969).

111 Francisco Martinez Found Guilty, LA RAZA, Oct. 15, 1968, at 12. Although without a direct byline, the Martinez article seems likely to have been written by Oscar Acosta. Acosta often wrote on legal matters for La Raza, not infrequently without identifying himself as the author, especially where, as in the Martinez piece, he was also partially the subject.

${ }^{112} I d$.

${ }^{113}$ Others, of course, drew different lessons from the conviction of Martinez. Dis- 
single misdemeanor conviction. However, Acosta did not see Martínez's conviction as an aberration; instead, Acosta viewed the conviction as indicative of the mistreatment that Chicanos could expect at the hands of the courts. In this way, Acosta seemed to draw on the lesson of legal repression from the background racial protest model. To the extent Acosta did so, two important results followed: First, because Acosta comprehended Martínez's conviction within a context that linked race, protest, and repression, the conviction effectively confirmed common sense; and second, as a confirming event, the conviction strengthened the salience of the other key features of the model. In part, this contributed to a belief among the activists that the police and courts would persecute them. When the law seemed to do so, it reinforced the basic connection between repression, protest, and race, and strengthened the salience of each of those individual elements as keys to comprehending transpiring events.

\section{E. East LA Thirteen Defense Strategy}

As noted above, the legal repression that Acosta perceived in the conviction of Martínez increased Acosta's pessimism regarding responsible protest. In addition, it influenced his sense of appropriate defense strategy. Convinced that he could not expect to win his clients' cases despite the merits of their arguments, the Martínez conviction led Acosta to believe that trials should be used to advance the movement generally, rather than to defend the individual. In explaining Martínez's conviction to the La Raza readers, Acosta insisted: "The only purpose to be served by a prolonged and extensive jury trial for a political case is to educate and organize around the trial itself."114 For Acosta, the Martínez conviction lowered to virtually nothing the perceived cost of using trials to advance the cause rather than to defend the client. Thus, in the midst of pretrial maneuvering in East LA Thirteen, the Martínez conviction served to solidify Acosta's sense that trials should serve not only, or even principally, to defend the accused, but rather to educate the masses and advance the movement.

trict Attorney Evelle Younger, for example, cited the guilty verdict as evidence that "the majority of the Mexican-American community in East Los Angeles continues to oppose the March school boycotts and the type of militant activity which they represent." Younger Declares: Eastside Majority Against Boycott, BELVEdere CiTIZEN, Oct. 10, 1968, at 1; see also Einstoss, supra note 105 ("The conviction ... illustrates that the responsible Mexican-American community does not support such boycotts.").

114 Francisco Martinez Found Guilly, supra note 106. 
Acosta readily transferred this lesson to East LA Thirteen. This is dramatically evident in the pages of La Raza, where Acosta published his article on the Martínez trial side by side with another, The East Los 13 Are Ready, setting out his strategy in the latter case. ${ }^{115}$ In the $L a$ Raza article, Acosta explained his strategy in East LA Thirteen as follows:

Chief Counsel for the 13, Chicano Lawyer Acosta, will attempt to prove that the hand-picked, blue ribbon Grand Jury violates the constitutional guarantees of equal protection of the laws.

"Not only do the judges discriminate against Chicanos," Acosta said, "but in fact they are discriminating against all poor and young and minority persons. The law says they must pick indiscriminately from a cross-section of the community, but in fact they pick their friends. ..."

... [E]very Superior Court Judge who has nominated anyone over the past ten years will be subpoenaed to testify why it is he never once, in ten years took a Mexican to dinner, let alone nominated one to serve his fellow citizens as a Grand Juror." 116

Acosta hoped to use East LA Thirteen to show, as he suggested in his more succinct explanation offered a month earlier, "that the Judges themselves are the bigots." tion contributed not just to general framing, but to decisions concerning the minutiae of daily conduct, including the orchestration of the defense in East LA Thirteen.

\section{F. Proving Mexican Non-White Identity}

There is a certain irony in how Acosta used East LA Thirteen to "educate and organize." In effect, Acosta and the defendants argued that because Mexicans were non-White, they suffered legal mistreatment. Yet, to the extent that their argument reflected the developing connection between protest, repression, and race, another conclusion also seems true: Because Mexicans suffered legal discrimination, they came to consider themselves non-White. The relationship ran both ways, from race to repression, but also from repression to race. Acosta and the defendants perceived only the first causal connection, assum-

${ }^{115}$ Zeta, The East Los 13 Are Ready, LA RAZA, Oct. 15, 1968, at 12. "Zeta" was used by Acosta as his middle name, and also frequently as his by-line.

116 Id.

117 La Raza Nueva 13, supra note 103. 
ing that their status as racial minorities engendered legal violence. It is also the case, however, that such violence contributed to the sense among Mexicans that they were non-White.

This dynamic between the defense strategy and the racial protest model that linked rebellion, repression, and race gives us new insight into the decision to argue a Fourteenth Amendment defense in East $L A$ Thirteen. Note that in order to advance this defense, Acosta not only had to show discrimination but also had to prove first that the defendants were part of an identifiable class of persons. In this context, rather than serving as an unfortunate preliminary hurdle that the defense had to overcome, the need to focus on Mexican identity emerged as a principal attraction of the equal protection argument. Acosta and the defendants hoped not only to proselytize in the courtroom regarding judicial racism, but also concerning Mexican racial identity itself. ${ }^{118}$

In his article on the defense strategy in East LA Thirteen, Acosta tells the La Raza readers: "Chicano Professor Ralph Guzman of Cal State will be the star and expert witness on the issue of who is $\mathrm{La}$ Raza," adding, "Guzman is probably the most knowledgeable expert on this subject in the Southwest, if not the entire United States, having devoted most of his life to this question." "' As Acosta explained earlier, "Professor Guzman will prove not only that the Chicano has been virtually excluded from the Grand Jury (30 out of 1,505) but, more importantly, that the Mexican American is a distinct person from the Anglo, with different language, values and culture." ${ }^{120}$ For Acosta, an essential aspect of the politics of East LA Thirteen involved establishing that Mexicans were separate and distinct. He would later describe the significance of the trial, and in particular expert testimony on Mexican identity, as follows:

[The East LA Thirteen] retained expert witnesses and used cardboard boxes full of documentary and statistical evidence to legally establish their identity as a people separate and distinct from the majority ....

${ }^{118}$ In part, the need to establish a new identity probably reflected dynamics common to most social movements. See supra notes 26-28 and accompanying text (discussing the role of identity formation in social movements). Yet, this redefinition also derived inspiration from the Black Power movement, which stressed a renaissance in identity. See CARMICHAEl \& HAMILTON, supra note 38, at 35 ("We shall have to struggle for the right to create our own terms through which to define ourselves and our relationship to the society, and to have these terms recognized.").

${ }_{119}$ Zeta, supra note 115 , at 12.

120 La Raza Nueva 13, supra note 103 , at 11. 
An expert urban sociologist lectured to a singularly silent court and counsel that the defendants did indeed belong to a separate and distinct group of persons despite their anthropological classification as Caucasians and their legal recognition as citizens.

... [The activists] emotionally and intellectually knew the potential implications of the testimony. ... The staccatoed, computerized, analytical statistics "justified" their very existence; what had been but an inchoate propaganda of their own now became a rational truth to serve them not only in their confrontations with the Anglo establishment, but more importantly with their painful attempts at the proselytizing of a Mexican community which condemned the walkouts along with their patent nationalism and which winced at the racial rancor in their verbosity. ${ }^{121}$

Acosta's recollection of the trial emphasized the significance of the expert testimony regarding Mexican identity. This testimony provided ammunition for the militants in their efforts to convince the Mexican community that they were non-White. ${ }^{122}$ Strikingly, however, Acosta suggested that the expert testimony also played a role in educating the defendants themselves. Though they professed a nonWhite identity as a basis for understanding their arrest and indictment, the defendants in fact were not yet fully convinced of their new identity-the trial itself served as an opportunity for the Mexican militants to prove not just to the courts and the community but to themselves that they were a non-White race. ${ }^{123}$

Acosta and the defendants in East LA Thirteen drew on a common sense connection between protest, race, and legal violence in coming to see themselves as non-White. They also drew on this linkage in expecting-and subsequently perceiving-judicial mistreatment. The

121 AcosTA, Racial Exclusion, supra note 50, at 283-85.

122 Marking group boundaries emerges as one of the important tasks in organizing social movements, and group boundaries are often drawn in relation to external understandings of group identity.

[F]or groups organizing to pursue collective ends, the process of asserting "who we are" often involves a kind of reverse affirmation of the characteristics attributed to it by the larger society. Boundary markers are . . central to the formation of collective identity because they promote a heightened awareness of a group's commonalities and frame interaction between members of the ingroup and the out-group.

Verta Taylor \& Nancy E. Whittier, Collective Identity in Social Movement Communities: Lesbian Feminist Mobilization, in FroNTIERS, supra note 22, at 104, 111.

${ }^{129}$ Cf. Gamson, supra note 25, at 68 ("Would-be challengers face the problem of overcoming a definition of the situation that they themselves may take as part of the natural order."). 
salience of the tripartite connection, accentuated over the course of the Black struggle for equality, provided the Mexican community with a framework of ideas and relationships for their social situation. Once brought into play, the racial struggle model generated expectations that, when fulfilled, strengthened the salience of this set of interconnections and reinforced the individual components. The triangular relationship between race, protest, and repression became a dynamic, self-reinforcing loop. ${ }^{124}$

\section{CONCLUSION}

The case study presented here tells a fairly particular story about the role played by legal violence in contributing to the emergence of a non-White identity among Mexicans in Los Angeles. It also tells us something more generally about the relationship between race and law.

The dramatic change in Mexican racial identity in 1968 confirms that race is a social construction and helps us to grasp what is further entailed thereby. In particular, this case study suggests that race operates as social knowledge along three interrelated levels: the conscious, the common sense, and the material. On the first level, race is a product of conscious thought and subject to purposeful manipulation.

${ }^{124}$ This loop reinforced itself in other ways as well. By shifting their attention from the schools to the courts and the police, the Chicano militants soon found themselves in an escalating and increasingly violent conflict. Some of this violence came from the activists, though most of it came from the police. Regarding social movements generally, Sidney Tarrow suggests "a rough division of labor: "[R]epressive forces do the largest part of the killing and wounding, while the groups they are seeking to control do most of the damage to objects." TARROW, POWER IN MOVEMENT, supra note 22, at 104 (quoting Charles TILly, From MOBILIZATION TO REvOlution 177 (1978)). Tarrow adds:

[In cycles of protest, $v$ ] iolence has a polarizing effect on conflict and alliance systems. It transforms the relations between challengers and authorities from a confused, many-sided game of allies, enemies, and bystanders into a bipolar one in which people are forced to choose sides, allies defect, and the state's repressive apparatus swings into gear. The threat of violence is a major power in movements, but it turns into a liability when potential allies become frightened, elites regroup in the name of social peace, and the forces of order learn to respond to it.

Id. Tarrow's observations seem to describe the trajectory of social protest in East Los Angeles between 1968 and 1972. Note that on the whole, recent social movement theory gives relatively little attention to violence and deviance, emphasizing instead, as Frances Fox Piven and Richard Cloward lament, a "normalized, overorganized, and conventionalized conception of political protest." Frances Fox Piven \& Richard A. Cloward, Normalizing Collective Protest, in FrONTIERS, supra note 22, at 301, 322. 
Strategizing by the Chicano activists around the issue of identity as a means of collective mobilization exemplifies the conscious construction of racial ideas. Race also reflects common sense-background ideas that channel conscious thought but are not explicitly recognized or purposefully relied upon. ${ }^{125}$ The strong identification of Chicano activists with Blackness, as well as their consistent reliance on the connections among protest, repression, and race, demonstrate how race functions as common sense. The operation of racial common sense led the activists to believe genuinely that they were Brown. They did not "choose" that identity, in the sense of recognizing themselves to be electing a race, or to be proclaiming a racial identity that they knew to be fabricated. Even as they struggled over their racial identity, they believed themselves to be wrestling with a fact, a truth that existed outside of themselves and beyond social control. The Chicanos accepted as part of the common sense of race that race was natural and physical, rather than social and cultural.

Racial knowledge involves more than conscious and common sense thought, though. It also reflects the material world. This actual world includes the variations in human physiognomy that racial ideology accentuates. More importantly, it encompasses embedded social practices that reflect racial thinking, and it includes the social and economic dislocations produced by long reliance on racial ideas. We must include in that real world the legal violence perpetrated by the courts against Mexicans. The East LA Thirteen prosecution only hints at the extent and reach of the violent repression practiced by the legal system against those constructed as racial minorities. ${ }^{126}$ Indeed, East Los Angeles itself - a culturally vibrant community, but also a segregated and impoverished enclave-stands as testimony to the material aspects of racial knowledge. The actual world in which we live, and the common practices by which we shape that world, form a core aspect in the social construction of race. This material component is inseparable from either conscious or common sense understandings of race-it is the world that we "know" and all too often render "natural."

125 Supra note 73 and accompanying text.

${ }^{126}$ On the day-to-day sort of violence perpetrated against Mexicans during the late 1960s, see U.S. COMM'N ON CIVIL RIGHTS, MEXICAN AMERICANS AND THE ADMINISTRATION OF JUSTICE IN THE SOUTHWEST (1970). See generally Robert Cover, Violence and the Word, 95 YALE L.J. 1601 (1986) (discussing the perpetration of violence through legal interpretation). 
As historical sociology, this Article explores the context in which Mexicans substantially changed their racial self-conception. Yet, this study offers broadly applicable lessons. I have argued earlier that law constructs race, though in doing so, I focused almost exclusively on law as a formal enterprise, as legislative action and judicial interpretation. ${ }^{127}$ The Chicano experience suggests that law constructs race in another way as well. It suggests that where legal violence against racialized communities is routine, that practice not only draws upon, but spurs, racial constructions. Specific studies must be done to understand the dynamics of racial formation vis-à-vis different communities at various times. Sadly, though, we can be confident that such studies will demonstrate that legal violence contributes to racial construction, both of non-Whites and Whites.

${ }^{127}$ IAN HANEY LÓPEz, White by LaW: The Legal Construction OF RACE (1996). 